\title{
Prevalence and determinants of unintended pregnancies amongst women attending antenatal clinics in Pakistan
}

Muhammad Atif Habib ${ }^{1,2^{*}}$, Camille Raynes-Greenow ${ }^{3}$, Sidrah Nausheen ${ }^{2}$, Sajid Bashir Soofi ${ }^{2}$, Muhammad Sajid ${ }^{2}$, Zulfiqar A Bhutta² and Kirsten I Black'

\begin{abstract}
Background: Unintended pregnancies are a global public health concern and contribute significantly to adverse maternal and neonatal health, social and economic outcomes and increase the risks of maternal deaths and neonatal mortality. In countries like Pakistan where data for the unintended pregnancies is scarce, studies are required to estimate its accurate prevalence and predictors using more specific tools such as the London Measure of Unplanned Pregnancies (LMUP).

Methods: We conducted a hospital based cross sectional survey in two tertiary care hospitals in Pakistan. We used a pre tested structured questionnaire to collect the data on socio-demographic characteristics, reproductive history, awareness and past experience with contraceptives and unintended pregnancies using six item the LMUP. We used Univariate and multivariate analysis to explore the association between unintended pregnancies and predictor variables and presented the association as adjusted odds ratios. We also evaluated the psychometric properties of the Urdu version of the LMUP.

Results: Amongst 3010 pregnant women, 1150 (38.2\%) pregnancies were reported as unintended. In the multivariate analysis age $<20$ years (AOR 3.5 1.1-6.5), being illiterate (AOR 1.9 1.1-3.4), living in a rural setting (1.7 1.2-2.3), having a pregnancy interval of $=<12$ months (AOR 1.7 1.4-2.2), having a parity of $>2$ (AOR 1.4 1.2-1.8), having no knowledge about contraceptive methods (AOR 3.0 1.7-5.4) and never use of contraceptive methods (AOR 2.3 1.4-5.1) remained significantly associated with unintended pregnancy. The Urdu version of the LMUP scale was found to be acceptable, valid and reliable with the Cronbach's alpha of 0.85 .

Conclusions: This study explores a high prevalence of unintended pregnancies and important factors especially those related to family planning. Integrated national family program that provides contraceptive services especially the modern methods to women during pre-conception and post-partum would be beneficial in averting unintended pregnancies and their related adverse outcomes in Pakistan
\end{abstract}

Keywords: Unintended pregnancies, Family planning, Contraceptive methods, London measure of unplanned pregnancies, Pakistan

\footnotetext{
*Correspondence: mhab4985@uni.sydney.edu.au; atif.habib@aku.edu

${ }^{1}$ Discipline of Obstetrics, Gynaecology and Neonatology, Central Clinical

School, University of Sydney, Sydney, NSW 2006, Australia

${ }^{2}$ Women and Child Health Division, Aga Khan University, Karachi, Pakistan

Full list of author information is available at the end of the article
}

(c) The Author(s). 2017 Open Access This article is distributed under the terms of the Creative Commons Attribution 4.0 International License (http://creativecommons.org/licenses/by/4.0/, which permits unrestricted use, distribution, and reproduction in any medium, provided you give appropriate credit to the original author(s) and the source, provide a link to the Creative Commons license, and indicate if changes were made. The Creative Commons Public Domain Dedication waiver (http://creativecommons.org/publicdomain/zero/1.0/) applies to the data made available in this article, unless otherwise stated. 


\section{Background}

Unintended pregnancies (pregnancies that are mistimed or unwanted) are a significant public health concern globally [1]. Of the estimated 210 million pregnancies that occur throughout the world each year, about $38 \%$ are unintended [2]. Twenty-two percent of global unintended pregnancies end in abortion, many of which take place with unsafe techniques and/or in unsafe circumstances and about $18 \%$ end in unplanned births, placing a substantial burden on health systems [1,2]. Most of the unintended pregnancies occur in developing countries largely due to poor literacy and lack of knowledge and access to contraceptive methods [3, 4]. In these settings unintended pregnancies contribute significantly to adverse health, social and economic outcomes [4-8] and increase the risks of maternal death and neonatal, infant and child mortality [9].

Pakistan is a developing country where contraceptive prevalence remains low (35.4\%) and the unmet need for family planning remains high (20.1\%) contributing to high fertility rate (3.8 births/woman) and large numbers of unintended pregnancies [10, 11]. Annually about 2.25 million abortions are conducted in Pakistan and the national abortion rate is 50 per 1000 women (15-49 years) [12]. As abortion remains illegal, many of the procedures are undertaken in unsafe circumstances, leading to complications and adverse outcomes. Indeed in 2012 over 62,000 women were treated for complications [13]. Unsafe abortion also contributes to maternal mortality in Pakistan [14-16].

The reported prevalence of unintended pregnancies in Pakistan is between 16-46\% [10-13]. Pakistan demographic and health surveys (PDHS) of 2006 and 2013 reported the prevalence of unintended pregnancies as $16 \%$ and $24 \%$ respectively $[10,11]$. This estimate was based only on a single question with a dichotomous response on mistimed or unwanted pregnancy at the time of conception. Another study which estimated the prevalence of unintended pregnancies in Pakistan as $46 \%$ was based on an indirect modeling for unintended pregnancies from induced abortion rates [13]. These measures are not sufficient to accurately measure the burden of unintended pregnancies. However there is a more accurate, reliable and validated tool. The London Measure of Unplanned Pregnancies (LMUP) is a six item scale that has been widely used in both developed and developing countries [17-30].

Given the adverse impact of unintended pregnancies on maternal and neonatal morbidity and mortality, and the lack of available data, our aim was to investigate the prevalence of unintended pregnancy using the LMUP and examine the socio-demographic predictors in Pakistan.

\section{Methods}

We conducted a hospital based cross sectional survey between January 2015 and April 2015 to achieve a sample size of 3000 women. We hypothesized that $40 \%$ of all pregnancies in the antenatal population in our study setting would be unintended, where the population is poor and there are high levels of illiteracy, little knowledge of contraception and where first pregnancies occur at a young age [11]. The sample size was estimated using a prevalence rate of unintended pregnancies of $40 \%$, a confidence level of $95 \%$, a design effect of 1.5 and a nonresponse rate of $10 \%$. The data collection was carried out in two tertiary care hospitals, one is located in Karachi city and the other one is located at district Dadu of Pakistan. Both hospitals have an average attendance of 100 females per day. Two female research assistants were trained and employed at both sites for data collection. All pregnant women attending the antenatal care clinic were eligible for recruitment.

We developed a participant information sheet, consent form and an interview administered structured questionnaire. All material was translated into Urdu and then back translated into English to ensure the accuracy. The questionnaire was pre tested in an antenatal clinic that was not a study site. Women were given the participant information sheet to read, or when they were unable to read, the study was explained to them in Urdu by the research assistant.

The questionnaire comprised of three sections; section one used the standard questions from demographic and health survey questionnaire to ascertain the characteristics and socio-demographic information of the respondent. Section two contained information about past reproductive history and family planning and section three used the Urdu version of pregnancy intention scale (LMUP) to ascertain unintended pregnancies. In this section questions were designed such that each response to the six questions was scored out of two, and summed to give a final pregnancy intendedness score between zero and 12. The intention scores were divided into three groups: zero-three (unplanned), four-nine (ambivalent) and ten-twelve (planned).

Unintended pregnancy was the main outcome variable. Women with pregnancy intendedness scores less than 10 (including both ambivalent and unplanned pregnancies) were considered as unintended. The explanatory variables for analysis were informed by the literature and their availability in the dataset and are described in Tables 1 and 2. Variables were grouped into two categories; socio-demographic factors and women related factors. In the socio-demographic factors; age, residence, education and wealth index were considered. Age at marriage, gestational age, parity, birth interval, history of previous miscarriage or abortion, family planning knowledge, 
Table 1 Description of independent variables

\begin{tabular}{|c|c|}
\hline Variables & Description \\
\hline \multicolumn{2}{|l|}{ Socio demographic factors } \\
\hline Area of residence & Urban and rural \\
\hline $\begin{array}{l}\text { Socio economic status } \\
\text { of the household }\end{array}$ & $\begin{array}{l}\text { SES was measured as quintiles of a linear } \\
\text { index derived from household assets and } \\
\text { utilities score, the wealth quintiles were } \\
\text { divided into five (poorest, poorer, middle, } \\
\text { richer, richest) }\end{array}$ \\
\hline \multicolumn{2}{|l|}{ Women related factors } \\
\hline Age & $\begin{array}{l}\text { Categorized as }<20 \text { years, } 20-24 \text { years, } \\
25-29 \text { years and }>30 \text { years }\end{array}$ \\
\hline Education & $\begin{array}{l}\text { Years of education completed (illiterate/ } \\
\text { years of education) }\end{array}$ \\
\hline Age of marriage & $\begin{array}{l}\text { Categorized as }=<20 \text { years and }>20 \text { years, } \\
\text { used as a proxy for age at first intercourse }\end{array}$ \\
\hline Gestational age & $\begin{array}{l}\text { Recorded in weeks and categorized as }< \\
28 \text { weeks and } 28 \text { or more weeks }\end{array}$ \\
\hline Parity & $\begin{array}{l}\text { Defined as the number of previous deliveries } \\
\text { and categorized as }=<2 \text { times and }>2 \text { times }\end{array}$ \\
\hline Birth interval & $\begin{array}{l}\text { Interval from one child's birth date until the } \\
\text { next child's birth date and categorized as } \\
<12 \text { months, } 12-24 \text { months and }>24 \text { months }\end{array}$ \\
\hline $\begin{array}{l}\text { History of abortion } \\
\text { or miscarriage }\end{array}$ & $\begin{array}{l}\text { Any history of previous miscarriage and } \\
\text { abortion and categorized as } 1=\text { Yes and } \\
\text { No }=2\end{array}$ \\
\hline $\begin{array}{l}\text { Knowledge about family } \\
\text { planning methods }\end{array}$ & $\begin{array}{l}\text { Ever heard of any family planning method } \\
\text { and categorized as } 1=\text { Yes and } \mathrm{No}=2\end{array}$ \\
\hline $\begin{array}{l}\text { Use of family planning } \\
\text { methods }\end{array}$ & $\begin{array}{l}\text { Ever used any family planning method and } \\
\text { categorized as } 1=\text { Yes and } \mathrm{No}=2\end{array}$ \\
\hline
\end{tabular}

source of knowledge about family planning and family planning use were considered in the women related factors. Age at marriage was used as a proxy for age at first intercourse which is difficult to ask as it is a culturally sensitive question.

The ethical review committee of Aga Khan University granted ethical approval (Ref: 3710-Ped-ERC-15). Written informed consent was obtained from all participants. In cases where the woman was illiterate, consent was documented by a thumbprint on the consent form and confirmed by a signature from a literate witness. All the names and personal information regarding the participants were kept confidential and all identifying information was removed from analysis.

The data were analyzed using IBM SPSS version 19 [31]. Initially the scoring of the responses from the data extracted from LMUP was done and the prevalence of unintended pregnancy was calculated using data from all six of the questions in the pregnancy intention instrument. Family planning profile of the participants was also established and comparison of contraception knowledge and use between the data of this study and PDHS 2012 was carried out. Univariate analyses were run between socio demographic factors and women related
Table 2 London Measure of Unplanned Pregnancies (LMUP) scale

\begin{tabular}{lll}
\hline Question & Answer & Score \\
\hline At the time of conception & Always use contraception & 0 \\
& Inconsistently us contraception & 1 \\
& Not use contraception & 2 \\
In terms of becoming & Wrong time & 0 \\
a mother & An OK time but not quite right & 1 \\
& Right time & 2 \\
Just before falling pregnant & Not intend to become pregnant & 0 \\
& Did not mind either way & 1 \\
& Intend to get pregnant & 2 \\
Just before falling pregnant & Not want a baby & 0 \\
& Have mixed feeling about having & 1 \\
& a baby & \\
& Want a baby & 2 \\
Before falling pregnant had & Never discussed children & 0 \\
you and your partner & Discuss children but no firm & 1 \\
& agreement & \\
Agreed to pregnancy & No action \\
Health actions before falling & 1 action \\
pregnant & 2 or more actions & 0 \\
\hline
\end{tabular}

${ }^{a}$ Health Actions include iron folic acid supplementation, cessation or reduction in smoking, tobacco/ Pan/ Gutka/

beetle nut chewing and seeking medical advice

factors. Degree of association was assessed using chi squared tests. The demographic characteristics with a $p$ value $<0.25$ were then examined using logistic regression analyses. In multivariate analysis adjusted odds ratios and 95\% confidence intervals were calculated to determine the degree of association between associated factors and pregnancy intention.

In order to validate the Urdu version of the scale we conducted psychometric analysis of the Urdu LMUP. We assessed the proportion of missing data and considered item endorsement, with item response option endorsements of $<80 \%$ considered to be acceptable $[21-23,26,30]$. To measure the reliability of scale, we evaluated the internal consistency by calculating the Cronbach's alpha statistic using the standard cut off point of 0.7 and also looked at the corrected item-total correlations [21-23, 26, 30]. We also did Principal component analysis to evaluate the internal structure of the LMUP. The scale would be considered valid if all items load onto one component with an Eigenvalue larger than one (i.e. are measuring the same construct) $[22,26,30]$.

\section{Results}

A total of 3010 women were included in the analysis with a mean gestational age of 26 weeks at the time of 
recruitment. Overall, 1150 (38.2\%) pregnancies in the antenatal population were unintended, of which 420 (13.9\%) were ambivalent and 730 (24.3\%) were unplanned. The remaining 1860 (61.8\%) pregnancies were considered intended. The socio demographic profile and women related factors are documented in Table 3. The majority of women (69.5\%) were aged more than 25 years, $51.6 \%$ were illiterate and half of the women lived in a rural area. Among the study population the two lowest and two highest wealth quintiles accounted for $40.2 \%$

Table 3 Frequency distribution of sociodemographic and women related variables

\begin{tabular}{|c|c|c|}
\hline Variable & Description & N (\%) \\
\hline \multirow[t]{2}{*}{ Pregnancy Intention } & Unintended (Score <10) & $1150(38.20)$ \\
\hline & Intended (Score >10) & $1860(61.7)$ \\
\hline \multirow[t]{2}{*}{ Area of Residence } & Rural & $1509(50.1)$ \\
\hline & Urban & $1501(49.9)$ \\
\hline \multirow[t]{5}{*}{ Wealth Index } & Poorest & 599 (19.9) \\
\hline & Second & $612(20.3)$ \\
\hline & Middle & $593(19.7)$ \\
\hline & Fourth & $604(20.1)$ \\
\hline & Richest & $602(20)$ \\
\hline \multirow[t]{4}{*}{ Pregnant women age } & $<20$ years & $135(4.5)$ \\
\hline & 20-24 Years & $783(26)$ \\
\hline & 25-29 Years & $1297(43.1)$ \\
\hline & $>=30$ Years & $795(26.4)$ \\
\hline \multirow{6}{*}{$\begin{array}{l}\text { Pregnant women's } \\
\text { education }\end{array}$} & Illiterate & $1552(51.6)$ \\
\hline & $\begin{array}{l}\text { Primary or less } \\
\text { (1-5 years of schooling) }\end{array}$ & $379(12.6)$ \\
\hline & Middle(6-8) & $159(5.3)$ \\
\hline & Matric(9-10) & $505(16.8)$ \\
\hline & Intermidiate \& above (>10) & $251(8.3)$ \\
\hline & Graduation and above (>12) & $164(5.4)$ \\
\hline \multirow{2}{*}{$\begin{array}{l}\text { Pregnant women's Age } \\
\text { at marriage }\end{array}$} & $\leq 20$ Years & $1656(55)$ \\
\hline & $>20$ Years & $1354(45)$ \\
\hline \multirow[t]{2}{*}{ Gestational age } & $<28$ weeks & $1467(48.7)$ \\
\hline & $>=28$ weeks & $1541(51.2)$ \\
\hline \multirow[t]{2}{*}{ Parity } & $<=2$ & $1161(53.9)$ \\
\hline & $>2$ & $994(46.1)$ \\
\hline \multirow[t]{2}{*}{ Birth Interval } & $\leq 12$ months & $1200(53.6)$ \\
\hline & $>12$ months & $1038(46.4)$ \\
\hline \multirow{2}{*}{$\begin{array}{l}\text { History of Abortion/ } \\
\text { Miscarriage }\end{array}$} & Yes & $523(17.4)$ \\
\hline & No & $2487(82.6)$ \\
\hline \multirow{2}{*}{$\begin{array}{l}\text { Knowledge about Family } \\
\text { Planning }\end{array}$} & No & $306(10.2)$ \\
\hline & Yes & 2704 (89.8) \\
\hline \multirow{2}{*}{$\begin{array}{l}\text { Ever Used family planning } \\
\text { methods }\end{array}$} & No & 2004 (66.6) \\
\hline & Yes & $1006(33.4)$ \\
\hline
\end{tabular}

and $40.1 \%$ respectively. We found that $55.0 \%$ of women were aged 20 years or younger at the time of their marriage, $46.1 \%$ had a parity of two or more and $53.6 \%$ reported a short birth interval of $\leq 12$ months. Among study participants $17.4 \%$ reported a previous miscarriage or abortion.

The family planning profile is outlined in Table 4 . Overall 89.9\% women had knowledge about at least one of the contraceptive methods but only $33.4 \%$ reported using them. For modern methods $96.2 \%$ of women had knowledge of the pill, followed by injectables (94.6\%), condoms $(88.3 \%)$, intrauterine devices $(83.5 \%)$, implants (73.5\%), female sterilisation (60.9\%), and male sterilisation $(15.1 \%)$. However use of contraception remained low with the most commonly used being condoms (19\%) followed by injectables $(9.7 \%)$, the pill $(9.6 \%)$, intra uterine device $(2.9 \%)$, and implants $(2.5 \%)$. For traditional methods only $14.5 \%$ and $34.5 \%$ of women had knowledge about the rhythm and withdrawal methods while $13.8 \%$ and $46.1 \%$ women reported using the rhythm method and withdrawal method respectively. Knowledge about emergency contraception was also low as only $25 \%$ of women were aware of it and only $23.7 \%$ reported having ever used it. The data regarding source of information for family planning revealed that health care providers $(59.9 \%)$ are the main source of information followed by peers (22.2\%), husbands (15.0\%) and the media (1.4\%). Our family planning data was consistent with the recent PDHS data and displays a notable contraceptive knowledge and practice gap (Fig. 1).

Table 5 shows the univariate association between unintended pregnancy and the independent variables. Unintended pregnancy in Pakistani women was significantly associated with age $<20$ years (OR 1.3 1.1-1.7), being poor (OR 1.8 1.3-2.3), being illiterate (OR 1.4 1.1-1.7), living in a rural setting (OR 1.5 1.1-1.8), having a pregnancy interval of $\leq 12$ months (OR 1.8 1.3-2.9), having a previous history of miscarriage/abortion (OR 1.8 1.2-2.1), having parity of $>2$ (OR $1.51 .2-1.8$ ), having no knowledge of any contraceptive method (OR 1.7 1.5-1.8) and never use of contraceptive methods (OR 1.2 1.1-3.8).

In the multivariate analysis (Table 6) being poor and having history of miscarriage/abortion no longer remained associated with unintended pregnancies but age $<20$ years (AOR 3.5 1.1-6.5), being illiterate (AOR 1.9 1.1-3.4), living in a rural setting (AOR 1.7 1.2-2.3), having a pregnancy interval of $=<12$ months (AOR 1.7 1.4-2.2), having a parity of $>2$ (AOR 1.4 1.2-1.8), having no knowledge about contraceptive methods (AOR 3.0 1.7-5.4) and never use of contraceptive methods (AOR 2.3 1.4-5.1) remained significantly associated with unintended pregnancy.

The psychometric analysis of the Urdu LMUP demonstrated relatively high internal consistency, with the 
Table 4 Family planning knowledge, use and source of information

\begin{tabular}{|c|c|c|c|c|c|c|c|}
\hline & Knowledge n (\%) & Ever used n (\%) & Health care providers n (\%) & Media n (\%) & Husband n (\%) & Peers n (\%) & Others $\mathrm{n}(\%)$ \\
\hline $\begin{array}{l}\text { Any family planning } \\
\text { method }\end{array}$ & 2706 (89.9) & $904(33.4)$ & $1621(59.9)$ & $39(1.44)$ & $406(15.0)$ & $602(22.2)$ & $36(1.3)$ \\
\hline Condoms & $2658(88.3)$ & $505(19.0)$ & $1555(58.5)$ & $40(1.5)$ & $827(31.1)$ & $226(8.5)$ & $11(0.4)$ \\
\hline Pill & $2896(96.2)$ & $278(9.6)$ & $1955(67.5)$ & $130(4.5)$ & $46(1.6)$ & $733(25.3)$ & $32(1.1)$ \\
\hline IUD & $2513(83.5)$ & $73(2.9)$ & $1819(72.4)$ & $30(1.2)$ & $25(1.0)$ & $608(24.2)$ & $30(1.2)$ \\
\hline Injectable & 2847 (94.6) & $276(9.7)$ & $1987(69.8)$ & $80(2.8)$ & $31(1.1)$ & $715(25.1)$ & $34(1.2)$ \\
\hline Implants & $2212(73.5)$ & $55(2.5)$ & $1712(77.4)$ & $13(0.6)$ & $20(0.9)$ & $453(20.5)$ & $13(0.6)$ \\
\hline Female sterilization & $1833(60.9)$ & $04(0.2)$ & $1510(82.4)$ & $16(0.9)$ & $31(1.7)$ & $236(12.9)$ & $38(2.1)$ \\
\hline Male Sterilization & $455(15.1)$ & $02(0.4)$ & $271(59.6)$ & $05(1.1)$ & $40(8.7)$ & $129(28.4)$ & $10(2.2)$ \\
\hline Emergency Contraception & $753(25.0)$ & $178(23.7)$ & $386(51.2)$ & $05(0.6)$ & $93(12.3)$ & $267(35.5)$ & $03(0.4)$ \\
\hline Rhythm & $436(14.5)$ & $60(13.8)$ & $199(45.7)$ & $04(0.9)$ & 125 (28.6) & $102(23.3)$ & $07(1.5)$ \\
\hline Withdrawal & 1038 (34.5) & 478 (46.1) & 158 (15.2) & $03(0.3)$ & $654(63.0)$ & 195 (18.8) & $28(2.7)$ \\
\hline
\end{tabular}

Cronbach's alpha score at 0.85 and the all item-rest correlations were 0.207 for item $1,0.483$ for item $2,0.487$ for item 3, 0.494 for item 4, 0.467 for item 5 and 0.235 for item 6 .

We did not observe any missing data (Table 7). The LMUP score distribution was non-normal and the median score was 10 (inter-quartile range 5-11). The principal component analysis confirmed that all six items loaded onto one component (Eigenvalue $=3.81$ ) and the six items component loadings were 0.146 for item 1, 0.865 for item 2, 0.870 for item 3, 0.902 for item 4, 0.815 for item 5 and 0.331 for item 6 . We also report the full range of the LMUP scores (Fig. 2).

\section{Discussion}

In our study the estimated prevalence of unintended pregnancies in women attending the antenatal care clinic was $38.2 \%$ which is consistent with the estimated global prevalence [1]. This estimate is higher than previously reported data of $16 \%$ and 24\% in PDHS 2006 and 2013
$[10,11]$ but lower than the $46 \%$ reported in the study conducted by Sathar et al. [12]. These previous studies used a dichotomous scale whereas we employed the six item LMUP [17-30, 32]. The prevalence of unintended pregnancies in our study is higher than the studies from Iran (33.7\%) [21], Kenya (24\%) [33], Ethiopia (27.9\%) [34] and Sudan (30.2\%) [35] but lower than in Nepal (41\%) [36], Papua New Guinea (49.4\%) [20], Tanzania (45.9\%) [37] and Ghana (70\%) [38]. The most relevant comparable data are those from Iran and Papua New Guniea [20, 21] who also used the LMUP, although in Papua New Guinea a five item partial LMUP was used as item 6 was dropped to be locally appropriate.

Our study showed that the likelihood of unintended pregnancies is significantly associated with age less than 20 years. This is consistent with the Papua New Guinean, Kenyan and Tanzanian data [20, 33, 37] and makes sense given that younger women have higher fertility, higher frequency of sexual intercourse, lower knowledge of contraceptive methods and higher rates of

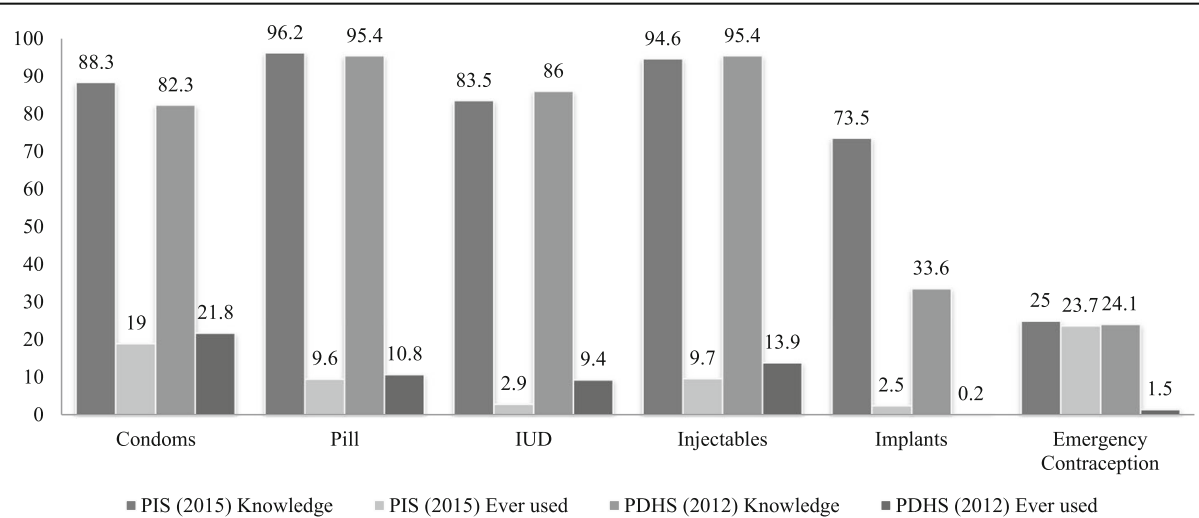

Fig 1 Comparison of contraception knowledge and use between survey for prevalence and determinants of unintended pregnancies among women attending antenatal clinics in Pakistan and PDHS 2012. **PIS Pregnancy Intension Survey (Present study), **PDHS Pakistan Demographic and Health Survey 
Table 5 Unadjusted association between unintended pregnancy and predictor variables, Pakistan 2015

\begin{tabular}{|c|c|c|c|}
\hline Variable & $\begin{array}{l}\text { Unintended } \\
\text { pregnancy n (\%) }\end{array}$ & OR & $p$ value \\
\hline \multicolumn{4}{|l|}{ Area of Residence } \\
\hline Rural & $670(58.3)$ & $1.5(1.1-1.8)$ & $<0.001$ \\
\hline Urban & $480(41.7)$ & Ref & \\
\hline \multicolumn{4}{|l|}{ Wealth Index } \\
\hline Poorest & $266(23.1)$ & $1.8(1.3-2.3)$ & $<0.001$ \\
\hline Second & $259(22.5)$ & $1.7(1.2-2.1)$ & $<0.001$ \\
\hline Middle & $244(21.2)$ & $1.6(1.1-2.0)$ & $<0.001$ \\
\hline Fourth & $199(17.3)$ & $1.1(0.9-1.4)$ & 0.311 \\
\hline Richest & $182(15.8)$ & Ref & \\
\hline \multicolumn{4}{|l|}{ Pregnant women age } \\
\hline$<20$ years & $41(3.6)$ & $1.3(1.1-1.7)$ & $<0.001$ \\
\hline 20-24 Years & $205(17.8)$ & $0.4(0.3-0.5)$ & $<0.001$ \\
\hline 25-29 Years & $519(45.1)$ & $0.7(0.6-0.8)$ & $<0.001$ \\
\hline$>=30$ Years & $385(33.5)$ & Ref & \\
\hline \multicolumn{4}{|l|}{$\begin{array}{l}\text { Pregnant women's } \\
\text { education }\end{array}$} \\
\hline Illiterate & $552(48)$ & $1.4(1.1-1.7)$ & 0.011 \\
\hline $\begin{array}{l}\text { Primary or less } \\
\text { (1-5 years of schooling) }\end{array}$ & $153(13.3)$ & $1.1(0.7-1.5)$ & 0.769 \\
\hline Middle (6-8) & $62(5.4)$ & $1.0(0.6-1.6)$ & 0.995 \\
\hline Matric (9-10) & $216(18.8)$ & $1.2(0.8-1.7)$ & 0.398 \\
\hline Intermidiate \& above (>10) & $103(9)$ & $1.1(0.7-1.6)$ & 0.683 \\
\hline Graduation and above (>12) & $64(5.6)$ & Ref & \\
\hline \multicolumn{4}{|l|}{$\begin{array}{l}\text { Pregnant women's } \\
\text { Age at marriage }\end{array}$} \\
\hline$\leq 20$ Years & $648(56.3)$ & $1.1(0.9-1.3)$ & 0.248 \\
\hline$>20$ Years & $502(43.7)$ & Ref & \\
\hline \multicolumn{4}{|l|}{ Gestational age } \\
\hline$<28$ weeks & $534(46.4)$ & $1.2(0.6-1.4)$ & 0.071 \\
\hline$>=28$ weeks & $616(53.6)$ & Ref & \\
\hline \multicolumn{4}{|l|}{ Parity } \\
\hline$>2$ & $528(51.4)$ & $1.5(1.2-1.8)$ & $<0.001$ \\
\hline$<=2$ & $500(48.6)$ & Ref & \\
\hline \multicolumn{4}{|l|}{ Birth Interval } \\
\hline$\leq 12$ months & $521(50.2)$ & $1.8(1.3-2.9)$ & 0.003 \\
\hline$>12$ months & $516(49.8)$ & Ref & \\
\hline \multicolumn{4}{|l|}{$\begin{array}{l}\text { History of Abortion/ } \\
\text { Miscarriage }\end{array}$} \\
\hline Yes & $259(22.5)$ & $1.8(1.2-2.1)$ & $<0.001$ \\
\hline No & 891 (77.5) & ref & \\
\hline
\end{tabular}

Table 5 Unadjusted association between unintended pregnancy and predictor variables, Pakistan 2015 (Continued)

\begin{tabular}{llll}
\hline Knowledge about & & & \\
Family Planning & & & \\
No & $95(8.3)$ & $1.7(1.5-1.9)$ & 0.007 \\
Yes & $1055(91.7)$ & ref & \\
$\begin{array}{l}\text { Ever Used family } \\
\text { planning methods }\end{array}$ & & & \\
No & $657(57.1)$ & $1.2(1.1-3.8)$ & $<0.001$ \\
Yes & $493(42.9)$ & ref & \\
\hline
\end{tabular}

contraceptive failure relative to older women [33, 37, 39, 40]. Likewise women who were illiterate were more likely to have an unintended pregnancy $[20,35,36]$ which is consistent with evidence documenting that literate women have a better understanding of their rights and responsibilities and have more freedom, control and participation in decisions around contraception use and family planning [41-44].

In our study parity was significantly associated with unintended pregnancies. Women who had a parity of greater than two were more likely to have an unintended pregnancy. This finding is comparable to studies conducted in other developing countries [20, 34, 35, 38, 45]. Similar to parity, short birth intervals of less than 12 months were also found to be significantly associated with unintended pregnancies in our study as has been noted elsewhere [20, 46, 47].

Consistent with the available literature [20, 33-38], our study found that unintended pregnancy is strongly associated with a lack of awareness of contraceptive methods. As contraceptive awareness has been found to be directly related to its' use [48-50] it is essential to implement initiatives to improve community knowledge about contraceptive methods. Our study also found that women who had never used contraception had twice at risk of having an unintended pregnancy compared to current users, as is consistent with the literature [20, 33-38, 51]. Furthermore, ever use of modern methods (including condoms, pills, IUDs, injectables, implants, male and female sterilization and emergency contraception) was very low and use of traditional methods high (Table 4).

This use of modern methods is alarmingly low, particularly the long acting reversible contraceptives (LARC) such as intrauterine devices (IUDs) and implants, possibly due to fear of infertility and side effects $[52,53]$. Our data is consistent with the recent PDHS which estimated the unmet need to be $20.1 \%$ [11, 54] which is well below that of neighboring countries like India, Nepal and Bangladesh [55-57]. It is evident that National family planning programs are failing to reach many women in need of contraception $[52,58]$. Studies 
Table 6 Adjusted association between unintended pregnancies and of predictor variables, Pakistan 2015

\begin{tabular}{|c|c|c|c|}
\hline Variable & $\begin{array}{l}\text { Unintended } \\
\text { pregnancy } \mathrm{n}(\%)\end{array}$ & AOR & $p$ value \\
\hline \multicolumn{4}{|l|}{ Area of Residence } \\
\hline Rural & $670(58.3)$ & $1.7(1.2-2.3)$ & $<0.001$ \\
\hline Urban & $480(41.7)$ & ref & \\
\hline \multicolumn{4}{|l|}{ Wealth Index } \\
\hline Poorest & $266(23.1)$ & $1.4(0.9-2.2)$ & 0.063 \\
\hline Second & $259(22.5)$ & $1.7(0.9-1.8)$ & 0.068 \\
\hline Middle & $244(21.2)$ & $1.6(0.8-1.8)$ & 0.087 \\
\hline Fourth & $199(17.3)$ & $1.1(0.8-1.4)$ & 0.311 \\
\hline Richest & $182(15.8)$ & ref & \\
\hline \multicolumn{4}{|l|}{ Pregnant women age } \\
\hline$<20$ years & $41(3.6)$ & $3.5(1.1-6.5)$ & 0.022 \\
\hline 20-24 Years & $205(17.8)$ & $1.0(0.7-1.4)$ & 0.937 \\
\hline 25-29 Years & $519(45.1)$ & $1.1(0.9-1.4)$ & 0.345 \\
\hline$>=30$ Years & $385(33.5)$ & ref & \\
\hline \multicolumn{4}{|l|}{$\begin{array}{l}\text { Pregnant women's } \\
\text { education }\end{array}$} \\
\hline Illiterate & $552(48)$ & $1.9(1.1-3.4)$ & 0.025 \\
\hline $\begin{array}{l}\text { Primary or less } \\
\text { (1-5 years of schooling) }\end{array}$ & $153(13.3)$ & $1.8(1.0-3.1)$ & 0.053 \\
\hline Middle (6-8) & $62(5.4)$ & $1.8(0.9-3.5)$ & 0.100 \\
\hline Matric (9-10) & $216(18.8)$ & $1.9(1.1-3.2)$ & 0.022 \\
\hline Intermidiate \& above (>10) & $103(9)$ & $1.5(0.8-2.6)$ & 0.195 \\
\hline Graduation and above $(>12)$ & $64(5.6)$ & ref & \\
\hline \multicolumn{4}{|l|}{ Parity } \\
\hline$>2$ & $528(51.4)$ & $1.4(1.2-1.8)$ & $<0.001$ \\
\hline$<=2$ & $500(48.6)$ & ref & \\
\hline \multicolumn{4}{|l|}{ Birth Interval } \\
\hline$\leq 12$ months & $521(50.2)$ & $1.7(1.4-2.2)$ & $<0.001$ \\
\hline$>12$ months & $516(49.8)$ & ref & \\
\hline \multicolumn{4}{|l|}{$\begin{array}{l}\text { History of Abortion/ } \\
\text { Miscarriage }\end{array}$} \\
\hline Yes & $259(22.5)$ & $1.1(0.7-1.8)$ & 0.080 \\
\hline No & 891 (77.5) & ref & \\
\hline \multicolumn{4}{|l|}{$\begin{array}{l}\text { Knowledge about } \\
\text { Family Planning }\end{array}$} \\
\hline No & $95(8.3)$ & $3.0(1.7-5.4)$ & $<0.001$ \\
\hline Yes & 1055 (91.7) & ref & \\
\hline \multicolumn{4}{|l|}{$\begin{array}{l}\text { Ever Used family } \\
\text { planning methods }\end{array}$} \\
\hline No & $657(57.1)$ & $2.3(1.4-5.1)$ & $<0.001$ \\
\hline Yes & 493 (42.9) & ref & \\
\hline
\end{tabular}

from Pakistan have demonstrated that lack of spousal communication, religious beliefs, concerns about infertility and side effects and supply side factors such as poor
Table 7 Endorsement and response options for the LMUP scale

\begin{tabular}{|c|c|c|c|}
\hline \multicolumn{2}{|l|}{$\begin{array}{l}\text { Endorsement of the PI items } \\
\text { and response option }\end{array}$} & \multicolumn{2}{|c|}{$\begin{array}{l}\text { LMUP } \\
\text { Pakistan }\end{array}$} \\
\hline Items & Category & $n$ & $\%$ \\
\hline \multirow[t]{3}{*}{ At the time of conception } & $\begin{array}{l}0 . \text { Always use } \\
\text { contraception }\end{array}$ & 642 & 21.3 \\
\hline & $\begin{array}{l}\text { 1. Inconsistently use } \\
\text { contraception }\end{array}$ & 219 & 7.3 \\
\hline & 2. Not use contraception & 2149 & 71.4 \\
\hline \multirow{3}{*}{$\begin{array}{l}\text { In terms of becoming a } \\
\text { mother }\end{array}$} & 0. Wrong time & 629 & 20.9 \\
\hline & $\begin{array}{l}\text { 1. An OK time but not } \\
\text { quite right }\end{array}$ & 145 & 4.8 \\
\hline & 2. Right time & 2236 & 74.3 \\
\hline \multirow[t]{3}{*}{ Just before falling pregnant } & $\begin{array}{l}0 . \text { Not intend to become } \\
\text { pregnant }\end{array}$ & 734 & 24.4 \\
\hline & $\begin{array}{l}\text { 1. Did not mind either } \\
\text { way }\end{array}$ & 198 & 6.6 \\
\hline & 2. Intend to get pregnant & 2078 & 69.0 \\
\hline \multirow[t]{3}{*}{ Just before falling pregnant } & 0. Not want a baby & 729 & 24.2 \\
\hline & $\begin{array}{l}\text { 1. Have mixed feelings } \\
\text { about having a baby }\end{array}$ & 110 & 3.7 \\
\hline & 2. Want a baby & 2171 & 72.1 \\
\hline \multirow[t]{3}{*}{$\begin{array}{l}\text { Before falling pregnant had } \\
\text { you and your husband }\end{array}$} & $\begin{array}{l}\text { 0. Never discussed } \\
\text { children }\end{array}$ & 601 & 20.0 \\
\hline & $\begin{array}{l}\text { 1. Discussed children but } \\
\text { no firm agreement }\end{array}$ & 274 & 9.1 \\
\hline & 2. Agreed to pregnancy & 2135 & 70.9 \\
\hline \multirow{3}{*}{$\begin{array}{l}\text { Health actions before falling } \\
\text { pregnant }\end{array}$} & 0. No Action & 1001 & 33.3 \\
\hline & 1. Action & 1267 & 42.1 \\
\hline & 2 or more Actions & 742 & 24.7 \\
\hline Total & & 3010 & 100.0 \\
\hline
\end{tabular}

access, lack of counseling and insufficient availability of modern methods are the major hurdles to the acceptance of modern contraceptive methods [59-61]. Antenatal and postnatal counseling programs in other countries have demonstrated they can improve contraceptive prevalence [62-65]. Similar initiatives could easily be integrated into the Pakistan lady health workers (LHW) program (which has a workforce of more than 100,000 LHWs) [66]. Of course increased availability of modern methods of contraception would need to accompany any such educational program.

After adjusting for other factors women living in rural areas exhibited increased odds of an unintended pregnancy compared to their urban counterparts, a finding consistent with previous studies in similar settings $[37,67,68]$, this is likely to be associated with the higher prevalence of poverty, illiteracy, poor contraceptive knowledge and little access to modern contraceptive methods and services in rural areas. Additionally rural women may not have autonomy 


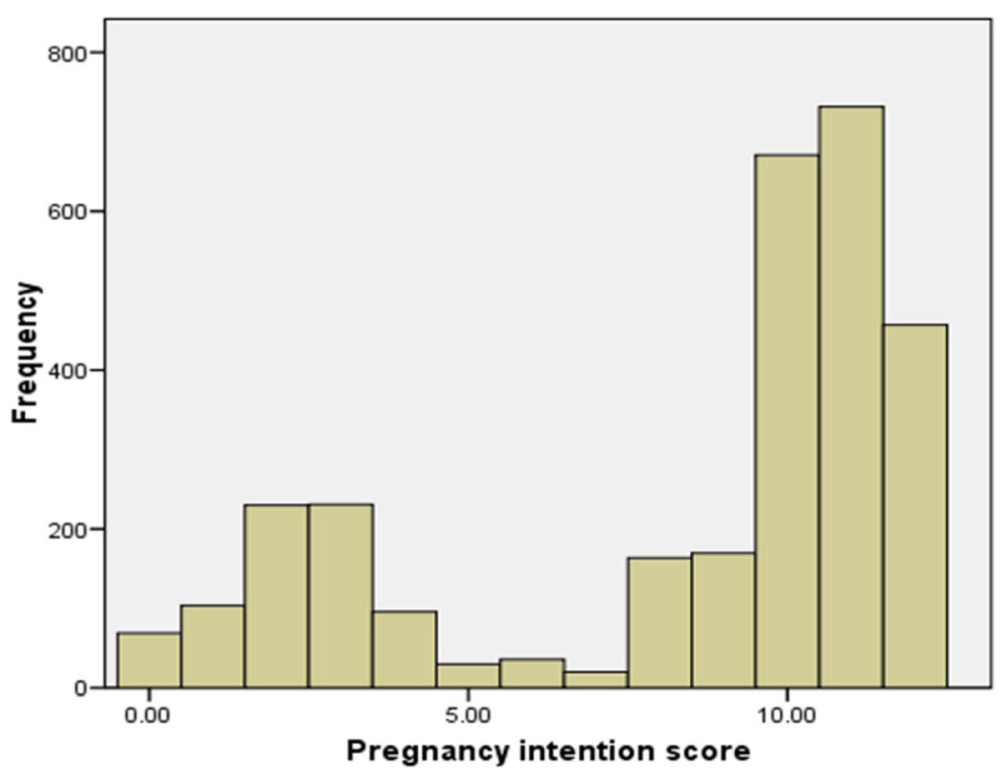

Fig 2 Distribution of Pregnancy intention score

in decision making and may have little or no say in family planning decisions $[68,69]$.

Our results indicate that the Urdu LMUP in Pakistan performed very well, with demonstrated reliability and validity in terms of acceptability, targeting, internal consistency and structural validity. The validation results are comparable (Table 7) with the similar validation studies for LMUP conducted in Iran, Malawi, India, United States and Brazil [21-23, 26, 30].

The use of a validated pregnancy intention scale (LMUP) to estimate unintended pregnancies was the main strength of our study, but there are some limitations. Firstly there is a possibility of recall bias due to retrospective nature of the questionnaire. Secondly the cross-sectional design does not allow causal inferences and lastly the results may not be generalizable to the whole country since the study was conducted only in two tertiary care hospitals. And finally is the lack of a test-retest analysis in the psychometric data for the stability of the scores.

Although efforts are being made by both private and public institutions, access to modern methods remains a challenge in Pakistan. Similarly the provision of safe abortion services remained a neglected area due to its illegal status and stigmatization [70]. Recent estimates suggest that about 25,000 unintended pregnancies and their related abortions and unplanned births could be averted over a 5 -year period only by changing $4 \%$ of current oral contraceptive users in Pakistan to LARC [71]. Community midwives and lady health visitors are well placed to provide LARC services [52] that will allow women the possibility of birth spacing and family limiting [72]. As many women in Pakistan do not have the freedom to decide about family planning it is essential that men are also engaged in education programs which have been found to effectively improve attitudes and behaviors, a decrease in the fertility and an increase in the contraceptive use [73].

\section{Conclusion}

The high prevalence of unintended pregnancies resulting in induced abortions and unplanned births in Pakistan highlight the urgent need for a concerted effort through a private and public partnership to improve the knowledge and access to modern contraceptive methods and safe abortion services. An integrated national family program that provides contraceptive services to women during pre-conception and post-partum would be beneficial in averting unintended pregnancies and their related adverse outcomes in Pakistan.

\section{Abbreviations}

IUD: Intra uterine device; LARC: Long acting reversible contraceptives; LHW: Lady health worker; LMUP: London measure of unplanned pregnancies; PDHS: Pakistan demographic and health survey

\section{Acknowledgements}

This manuscript is a part of MAH's thesis to fulfill the requirement for a PhD at the University of Sydney. We are grateful to the Women and Child Health Division, Aga Khan University for providing the opportunity and resources for conducting the survey. We are also thankful to the University of Sydney for funding MAH's PhD scholarship (IPRS/APA) and CRG's funding through an NHMRC career development fellowship. We would like acknowledge the efforts of Mr. Mushtaq Mirani, Mr. Qamar Junejo, Mr. Abid Hussain, Miss Zarnigar and Miss Nasima for their efforts and hard work in the survey. We would also like to thank all the participants who took part in the study. 


\section{Funding}

The study was funded by Swiss Red Cross, Switzerland.

\section{Availability of data and material}

The datasets used and analyzed during the current study is available from the corresponding author on reasonable request.

\section{Authors' contributions}

MAH, KB, CRG conceived design and idea of the survey. MAH, SBS and SN were involved in data collection. $C R G, K B$ and $Z A B$ provided advice on data analysis. MAH and $S M$ conducted the data analysis. MAH prepared the manuscript. CRG, KB, SN, SBS and ZAB reviewed the manuscript. All authors seen the final draft and approved the manuscript.

\section{Competing interests}

The authors declare that they have no competing interest.

\section{Consent for publication}

Not applicable.

\section{Ethics approval and consent to participate}

This study was conducted under approval by institutional review boards at the Aga Khan University, Karachi, Pakistan. Written consent was taken from all participants.

\section{Publisher's Note}

Springer Nature remains neutral with regard to jurisdictional claims in published maps and institutional affiliations.

\section{Author details}

'Discipline of Obstetrics, Gynaecology and Neonatology, Central Clinical School, University of Sydney, Sydney, NSW 2006, Australia. ${ }^{2}$ Women and Child Health Division, Aga Khan University, Karachi, Pakistan. ${ }^{3}$ Sydney School of Public Health, University of Sydney, Sydney, NSW 2006, Australia.

\section{Received: 29 February 2016 Accepted: 22 May 2017}

\section{Published online: 30 May 2017}

\section{References}

1. Centers for Disease Control: Unintended Pregnancy Prevention: Home http://www.cdc.gov/reproductivehealth/unintendedpregnancy. [Accessed on Jan 2016]

2. Singh S, Sedgh G, Hussain R. Unintended pregnancy: worldwide levels, trends, and outcomes. Stud Family Planning. 2010;41:241-50.

3. Klima CS. Unintended pregnancy: consequences and solutions for a worldwide problem. J Midwifery Womens Health. 1998;43:483-91.

4. Dixit $P$, Ram F, Dwivedi LK. Determinants of unwanted pregnancies in India using matched case control designs. BMC Pregnancy Childbirth. 2012;12:84.

5. Gipson JD, Koenig MA, Hindin MJ. The effects of unintended pregnancy on infant, child, and parental health: A review of the literature. Stud Family Planning. 2008;39:18-38.

6. Mohllajee AP, Curtis KM, Morrow B, Marchbanks PA. Pregnancy intention and its relationship to birth and maternal outcomes. Obstet Gynecol. 2007; 109(3):678-86.

7. Monea $\mathrm{E}$, Thomas A. Unintended pregnancy and taxpayer spending Perspect Sex Reprod Health. 2011:43:88-93.

8. Shah PS, Balkhair T, Ohlsson A, Beyene J, Scott F, Frick C. Intention to become pregnant and low birth weight and preterm birth: a systematic review. Maternal Child Health J. 2011;15:205-16. doi:10.1007/s10995-0090546-2

9. Singh S, Darroch JE, Ashford LS, Vlassoff M. The Costs and Benefits of Investing in Family Planning and Maternal and Newborn Health 2009 Available online at https://www.guttmacher.org/sites/default/files/report_ pdf/AddingltUp2009.pdf. Accessed Jan 2016.

10. Pakistan Demographic and Health Survey 2006-7. Islamabad and Calverton, MA: National Institute of Population Studies and Macro International Inc:; 2008. https://dhsprogram.com/pubs/pdf/FR200/FR200.pdf.

11. Pakistan Demographic and Health Survey 2012-13. Islamabad and Calverton MA: National Institute of Population Studies and ICF International; 2013. https://dhsprogram.com/pubs/pdf/FR290/FR290.pdf. [Accessed on Jan 2016]
12. The Population council. Report on induced abortions and unintended pregnancies in Pakistan, 2014. http://www.popcouncil.org/uploads/pdfs/ 2014RH_PostabortionCare_Pakistan.pdf [Accessed Jan 2016]

13. Sathar Z, Singh S, Rashida G, Shah Z, Niazi R. Induced abortions and unintended pregnancies in Pakistan. Stud Fam Plann. 2014;45(4):471.

14. Gilani S, Azeem P. Induced abortion: a clandestine affair. J Postgrad Med Inst. 2005;19(4):412-5.

15. Saleem S, Fikree F. Induced abortions in low socio-economic settlements of Karachi, Pakistan: Rates and women's perspectives. J Pakistan Med Assoc. 2001;51(8):275-8.

16. Madhu Das C, Srichand P. Maternal mortality and morbidity due to induced abortion in Hyderabad. J Liaquat Univ Med Health Sci. 2005;5(2):62-5.

17. Lakha F, Glasier A. Unintended pregnancy and use of emergency contraception among a large cohort of women attending for antenatal care or abortion in Scotland. Lancet. 2006:368:1782-7.

18. Schunmann C, Glasier A. Measuring pregnancy intention and its relationship with contraceptive use among women undergoing therapeutic abortion. Contraception. 2006;73:520-4.

19. Rassi A, Wattimena J, Black K. Pregnancy intention in an urban Australian antenatal population. Aust N Z J Public Health. 2013;37:568-73.

20. Sanga K, Mola G, Wattimena J, Justesen A, Black Kl. Unintended pregnancy amongst women attending antenatal clinics at the Port Moresby General Hospital. Aust N Z J Obstet Gynaecol. 2014;54:360-5.

21. Roshanaei S, Shaghaghi A, Jafarabadi MA, Kousha A. Measuring unintended pregnancies in postpartum Iranian women: validation of the London Measure of Unplanned Pregnancy. EMHJ. 2015;21:8.

22. Hall J, Barrett G, Mbwana N, Copas A, Stephenson J. Understanding pregnancy planning in a low-income country setting: validation of the London measure of unplanned pregnancy in Malawi. BMC Pregnancy Childbirth. 2013:13(1):200.

23. Rocca $\mathrm{CH}$, Krishnan S, Barrett G, Wilson M. Measuring pregnancy planning: an assessment of the London measure of unplanned pregnancy among urban, South Indian women. Demogr Res. 2010;23:293.

24. Borges AL, Cavalhieri FB, Hoga LA, Fujimori E, Barbosa LR. Pregnancy planning: prevalence and associated aspects. Revista da Escola de Enfermagem da USP. 2011:45(SPE2):1679-84.

25. Stephenson J, Patel D, Barrett G, Howden B, Copas A, Ojukwu O, Pandya P, Shawe J. How do women prepare for pregnancy? Preconception experiences of women attending antenatal services and views of health professionals. PloS One. 2014;9(7):e103085.

26. Morof D, Steinauer J, Haider S, Liu S, Darney P, Barrett G. Evaluation of the London Measure of Unplanned Pregnancy in the a United States population of women. PloS One. 2012;7(4):e35381.

27. Cheney K, Sim KA, D'Souza M, Pelosi M, Black Kl. Unintended pregnancy amongst an early pregnancy clinic cohort: identifying opportunities for preventative health interventions Australian and New Zealand. J Obstet Gynaecol. 2016;56(4):426-31.

28. Yeatman S, Smith-Greenaway E. The relationship between pregnancy plannedness and parental and child health in Malawi. Contraception. 2016:94(4):424

29. Bexhell H, Guthrie K, Cleland K, Trussell J. Unplanned pregnancy and contraceptive use in Hull and East Yorkshire. Contraception. 2016;93:233-5.

30. Borges ALV, Barrett G, dos Santos OA, Nascimento NC, Cavalhieri FB, Fujimori E. Evaluation of the psychometric properties of the London measure of unplanned pregnancy in Brazilian Portuguese. BMC Pregnancy Childbirth. 2016:16:244

31. IBM Corp. IBM SPSS Statistics for Windows, Version 19.0. Armonk: IBM Corp; 2010.

32. Barrett G, Smith SC, Wellings K. Conceptualisation, development, and evaluation of a measure of unintended pregnancy. J Epidemiol Community Health. 2004;58:426-33.

33. Ikamari L, Izugbara C, Ochako R. Prevalence and determinants of unintended pregnancy among women in Nairobi Kenya. BMC Pregnancy Childbirth. 2013;13:69

34. Kassa N, Berhane Y, Worku A. Predictors of unintended pregnancy in Kersa, Eastern Ethiopia, 2010. Reprod Health. 2012;9(1):1.

35. Sabahelzain MM, Abdalla SM, Meraj SA, Mohamed E, Almansour MA, Medan KT, Awad FE. Prevalence and factors associated with unintended pregnancy among married women in an urban and rural community, Khartoum state Sudan. Global J Med Public Health. 2014:3(4):1-9.

36. Adhikari R, Soonthorndhada K, Prasartkul P. Correlates of unintended pregnancy among currently pregnant married women in Nepal. BMC Int Health Human Rights. 2009;9(1):1 
37. Exavery A, Kanté AM, Njozi M, Tani K, Doctor HV, Hingora A, Phillips JF. Predictors of mistimed, and unwanted pregnancies among women of childbearing age in Rufiji, Kilombero, and Ulanga districts of Tanzania. Reprod Health. 2014;11(1):1.

38. Eliason S, Baiden F, Yankey BA, Awusabo-Asare K. Determinants of unintended pregnancies in rural Ghana. BMC Pregnancy Childbirth. 2014;14(1):1.

39. Henshaw SK. Unintended pregnancy in the United States. Fam Plann Perspect. 1998;30:24-9.

40. Trussell J. Contraceptive failure in the United States. Contraception. 2004;70:89-96.

41. Acharya Y. Women's education and intra-household autonomy: evidence from Nepal. J Dev Soc Transformation. 2008;5(1):15-20.

42. Maitra P. Effect of socioeconomic characteristics on age at marriage and total fertility in Nepal. J Health, Popul Nutr. 2004;22:84-96.

43. Boonto P. Women's decision - making power in the rural family in Northeastern Thailand. Bangkok: Diss NIDA; 2008

44. Chanda SK, Howlader MH, Nahar N. Educational status of the married women and their participation at household decision making in rural Bangladesh. Int J Adv Res Technol. 2012;1(6):137-46.

45. Cheraghi P, Poorolajal J, Moeini B, Cheraghi Z. Predictors of unintended pregnancy among married women in Hamadan, Western Iran: A CaseControl Study. Iranian J Public Health. 2013;42(8):854.

46. Heller R, Cameron S, Briggs R, Forson N, Glasier A. Postpartum contraception: a missed opportunity to prevent unintended pregnancy and short inter-pregnancy intervals. J Fam Plann Reproduct Health Care. 2016; 42(2):93-8.

47. Wolf J, DeFranco EA, Chen A, Bessett D, Kelly E. Unintended pregnancy: characteristic social determinants and risk factors for adverse birth outcomes [59]. Obstet Gynecol. 2015;125:27S.

48. Saleem S, Bobak M. Women's autonomy, education and contraception use in Pakistan: a national study. Reprod Health. 2005;2(1):1.

49. Al Riyami A, Afifi M, Mabry RM. Women's autonomy, education and employment in Oman and their influence on contraceptive use. Reprod Health Matters. 2004;12:144-54.

50. Moursund A, Kravdal O. Individual and community effects of women's education and autonomy on contraceptive use in India. Popul Stud. 2003; 57:285-301.

51. Adanikin Al, Onwudiegwu U, Loto OM. Influence of multiple antenatal counseling sessions on modern contraceptive uptake in Nigeria. Eur J Contracept Reprod Health Care. 2013;18(5):381-7.

52. Hameed W, Azmat SK, Ishaque M, Hussain W, Munroe E, Mustafa G, Khan OF, Abbas G, Ali S, Asghar QJ, Ali S. Continuation rates and reasons for discontinuation of intra-uterine device in three provinces of Pakistan: results of a 24-month prospective client follow-up. Health Res Policy Syst. 2015; 13(1):37.

53. Peipert JF, Zhao Q, Allsworth JE, Petrosky E, Madden T, Eisenberg D, Secura G. Continuation and satisfaction of reversible contraception. Obstet Gynecol. 2011;117(5):1105.

54. MacQuarrie KLD. Unmet Need for Family Planning among Young Women: Levels and Trends. DHS Comparative Reports No. 34. Rockville: ICF International; 2014

55. International Institute for Population Sciences (IIPS). Macro International: National Family Health Survey (NFHS-3), 2005-06. India: IIPS; 2007.

56. Ministry of Health and Population (MOHP) [Nepal], New ERA, ICF International Inc. Nepal Demographic and Health Survey 2011. Kathmandu and Calverton: MOHP, New ERA, and ICF International; 2012.

57. National Institute of Population Research and Training (NIPORT), Mitra and Associates, Macro International. Bangladesh Demographic and Health Survey 2007. Dhaka and Calverton: NIPORT, Mitra and Associates, and Macro International; 2009

58. Khan AA, Khan A, Abbaas K, Tirmizi SF, ul Islam Z. The context and limitations of female sterilization services in Pakistan. J Pakistan Med Assoc. 2013;63(4 Suppl 3):S21-6.

59. Hardee K, Leahy E. Population, fertility and family planning in Pakistan: a program in stagnation. Popul Action Int. 2008;3:3.

60. Fikree FF, Khan A, Kadir MM, Sajan F, Rahbar MH. What influences contraceptive use among young women in urban squatter settlements of Karachi, Pakistan? Int Fam Plann Perspect. 2001;27:130-6.

61. Batool Z, Sabahat $H_{\text {., }}$ Reasons for low modern contraceptive use, insights from Pakistan and neighbouring countries. 2015. http://www.popcouncil. org/uploads/pdfs/2015RH_LitReview-RAF.pdf. [Accessed on Jan 2016]
62. Pazol K, Zapata LB, Tregear SJ, Mautone-Smith N, Gavin LE. Impact of contraceptive education on contraceptive knowledge and decision making: a systematic review. Am J Prev Med. 2015;49(2):S46-56.

63. Bolam A, Manandhar DS, Shreshtha P, Ellis M, Costello AM. The effects of postnatal health education for mothers on infant care and family planning practices in Nepal: a randomised controlled trial. Br Med J. 1998;316(7134):805-11.

64. Saeed GA, Fakhar S, Rahim F, Tabassum S. Change in trend of contraceptive uptake-effect of educational leaflets and counseling. Contraception. 2008; 77(5):377-81.

65. Lee JT, Tsai JL, Tsou TS, Chen MC. Effectiveness of a theory-based postpartum sexual health education program on women's contraceptive use: a randomized controlled trial. Contraception. 2011;84(1):48-56.

66. National Programme for Family Planning \& Primary Health Care, Pakistan. http://www.healthkp.gov.pk/index.php/national-program-for-familyplanning-primary-health-care-lhws-program/. Accessed Jan 2016.

67. Ferdousi SK, et al. Unmet need of family Planning among rural women in Bangladesh. J Dhaka Med Coll. 2010;19(1):11-5.

68. Mekonnen W, Worku A. Determinants of low family planning use and high unmet need in Butajira District, South Central Ethiopia. Reprod Health. 2011:8:37.

69. Creanga AA, Gillespie D, Karklins S, Tsui AO. Low use of contraception among poor women in Africa: an equity issue. Bull World Health Organization. 2011:89(4):258-66.

70. Vlassoff $\mathrm{M}$ et al., Abortion in Pakistan, In Brief, New York: Guttmacher Institute, 2009, No. 2. Available at https://www.guttmacher.org/sites/default/ files/pdfs/pubs/IB Abortion-in-Pakistan.pdf. [Accessed on Jan 2016]

71. Bakamjian L, Curtis C. Meeting national goals and people's needs with LA PMs. New York: United States Agency for International Development; 2013.

72. Pasha O, Goudar SS, Patel A, Garces A, Esamai F, Chomba E, Moore JL, Kodkany BS, Saleem S, Derman RJ, Liechty EA. Postpartum contraceptive use and unmet need for family planning in five low-income countries. Reproductive health. 2015;12(2):1.

73. Ashfag S, Sadiq M. Engaging the missing link: evidence from FALAH for Involving Men in Family Planning in Pakistan", Case Study. Washington, DC: Population Council, the Evidence Project; 2015. Available at http:// evidenceproject.popcouncil.org/wp-content/uploads/2015/07/7.27.2015 Engaging-the-Missing-Link-Meeting-Report_FINAL.pdf. [Accessed on Jan 2016].

\section{Submit your next manuscript to BioMed Central and we will help you at every step:}

- We accept pre-submission inquiries

- Our selector tool helps you to find the most relevant journal

- We provide round the clock customer support

- Convenient online submission

- Thorough peer review

- Inclusion in PubMed and all major indexing services

- Maximum visibility for your research

Submit your manuscript at www.biomedcentral.com/submit 